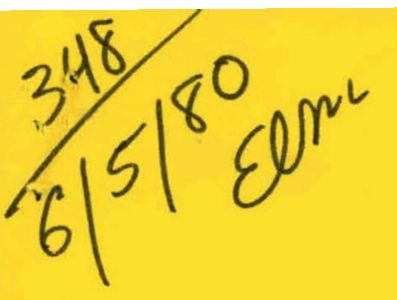

DOE/NASA CONTRACTOR

DOE/ NASA CR-161435 REPORT

\title{
SOLAR HEATING SYSTEM INSTALLED AT BLAKEDALE PROFESSIONAL CENTER, GREENWOOD, S. C. - FINAL REPORT
}

Prepared by

W. E. Gilbert \& Associates, Inc.

P. O. Box 519

Greenwood, S. C. 29646

Under Contract EX-76-C-01-2389

Monitored by

National Aeronautics and Space Administration

George C. Marshall Space Flight Center, Alabama 35812

For the U. S. Department of Energy

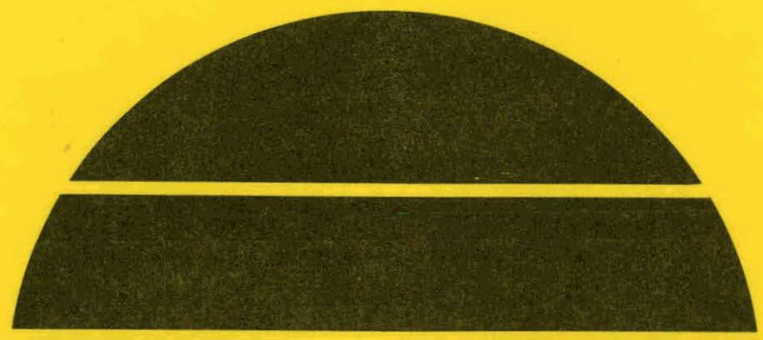

\section{U.S. Department of Energy}




\section{DISCLAIMER}

This report was prepared as an account of work sponsored by an agency of the United States Government. Neither the United States Government nor any agency Thereof, nor any of their employees, makes any warranty, express or implied, or assumes any legal liability or responsibility for the accuracy, completeness, or usefulness of any information, apparatus, product, or process disclosed, or represents that its use would not infringe privately owned rights. Reference herein to any specific commercial product, process, or service by trade name, trademark, manufacturer, or otherwise does not necessarily constitute or imply its endorsement, recommendation, or favoring by the United States Government or any agency thereof. The views and opinions of authors expressed herein do not necessarily state or reflect those of the United States Government or any agency thereof. 


\section{DISCLAIMER}

Portions of this document may be illegible in electronic image products. Images are produced from the best available original document. 
Th1s report was prepared to document work sponsored by the United States Govermment. Ne1ther the United States nor 1ts agents the United Statas Department of Energy, the United States National Aeronautics and Space Adminlstration, nor any federal employees, nor any of their contractors, subcontractors or their employees, wake any warranty, express or 1mpl1ed, or assume any legal liability or responstbility for the accuracy, completeness, or usefulness of any information, apparatus, product or process disclosed, or represent that its use would not infringe privately owned rights. 
TECHNICAL REPORT ST ANDARD TITLE PAGE

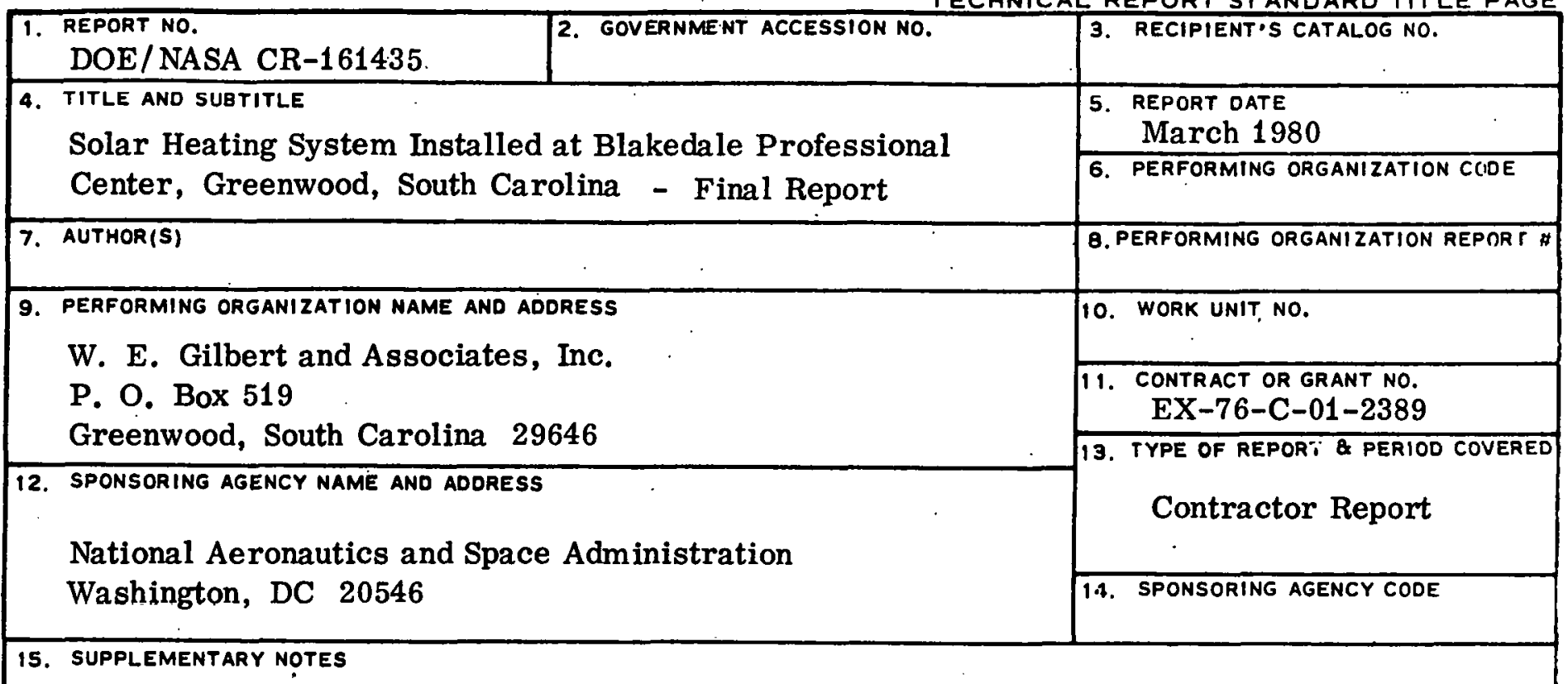

This work was done under the technical management of Mr. Valmore Fogle, Marshall Space Flight Center, Alabama.

16. ABSTRACT

This document provides information on the solar heating system installed at the Blakedale Professional Center, in Greenwood, South Carolina. The information consists of site and building description, solar system description, performance evaluation, system problems and installation drawings.

The solar system was designed to provide approximately 85 per cent of the building's heating requirements. The system was installed concurrently with building construction and heats 4,440 square feet of the building. There are 954 square feet of liquid flat-plate collectors that are roof-mounted and have a drain-down system to protect the collectors from freezing. A 5,000 gallon steel, polyurethane insulated tank buried underground provides storage. The system was fully instrumented for performance evaluation and integrated into the National Solar Data Network.

\begin{tabular}{|c|c|c|c|}
\hline 17. KEY WOROS & ; & $\begin{array}{l}\text { 18. DISTRIBUTION STATEMENT UC59a } \\
\text { Unclassified-Unlimited } \\
\text { WILLIAM A. BROOKSBANK, JR } \\
\text { Mgr, Solar Energy Applications }\end{array}$ & Projects \\
\hline $\begin{array}{l}\text { 19. SECURITY CLASSIF. (of this roport) } \\
\text { Unclassified }\end{array}$ & $\begin{array}{l}\text { 20. SECURITY CLAS } \\
\text { Unclassifi }\end{array}$ & \begin{tabular}{|l|c|} 
SIf. (ol thlo pQgo) & 21. NO. OF PAGES \\
33
\end{tabular} & $\begin{array}{ll}\text { 22. } & \text { PRICE } \\
& \text { NTIS }\end{array}$ \\
\hline
\end{tabular}


THIS PAGE

\section{WAS INTENTIONALLY LEFT BLANK}


TABLE OF CONTENTS

ITEM

PAGE

I. Introduction

II . Summary

III. Site and Building Description

IV. Solar System Description

A. Collector Array

B. Starage Systen

C. Transport Fluid

D. Transport System

E. Space Heating System

F. System Control

1. Control Logic

2. Control Parameters

3. Solar Collection System

V. Performance Evaluation

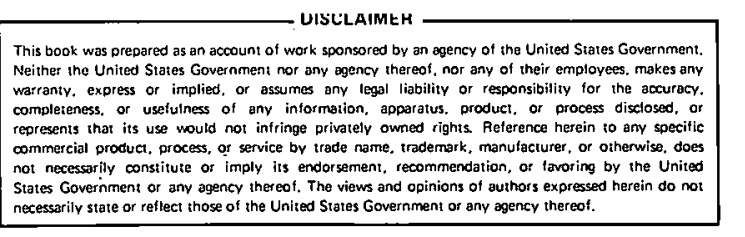

VI. System Problems necessarily state or reflect those of the United States Government or any ogency thereof.

A. Collector Breakage

B. Dropping Storage Tank Temperatures

C. Controls

VII. Appendix 


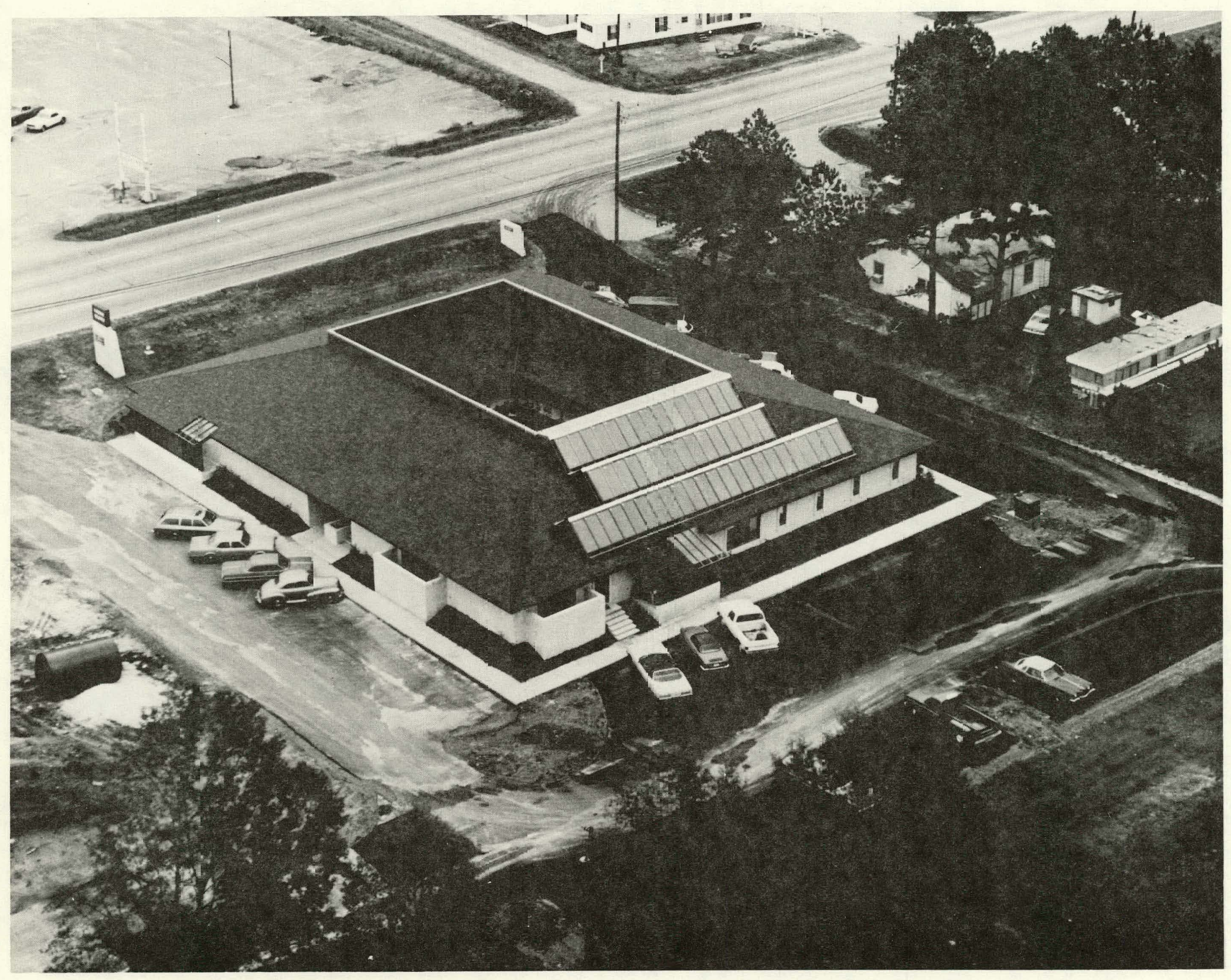

BLAKEDALE PROFESSIONAL CENTEZ - SOLAR COLLECTORS ON ROOF 
I. INTRODUCTION

W. E. Gilbert and Associates, Inc., architects and engineers, started planning a new office complex for a client, Blakedale Professional Center, Inc., in the fall of 1974 with the idea in mind that WEG/A would be one of the building tenants and that the office suite occupied by the firm would be designed so that it would readily accept the addition of a hydronic solar heating system. In early March, 1975, the decision was made to proceed with construction of the solar system and subsequently apply for a then upcoming ERDA Program Opportunity Grant as had been outlined in the Solar Demonstration Act approved by Congress. The Construction of the solar system is one hundred (100\%) percent complete and the building has been occupied since September, 1975.

\section{SUMMARY}

The following is a brief summary of the Blakedale Professional Center solar installation. Major features of this system include: COLLECTOR: Liquid, Flat Plate FREEZE PROTECTION: Drain-down APPLICATION: Heating, Hot Water STORAGE: Liquid, Exterior, Buried NEW/RETROFIT : : NeW PERFORMANCE EVALUATION INSTRUMENTATION: Yes SITE-SPECIFIC FEATURES: Reflectors, Heat Pump 
Space heating and domestic hot water heating is provided by a solar energy system utiliziny, 9.54 square feet of liquid flat plate collectors for a 10,000 square foot, one-story office building, Blakedale Professional Center, in Greenwood, South Carolina. The system was installed concurrent with building construction and heats 4,440 square feet of the building.

The collectors are roof-mounted in three banks on wooden, sawtooth type supports with aluminized mylar reflectors on the back of the supports. The collectors are double-glazed with tempered glass and have copper absorber plates and a non-selective black coating. A drain down system protects the collectors from freezing.

A 5,000-gallon steel storage tank, covered with polyurethane insulation, is buried underground approximately 50 feet from the building.

The heat from the tank is transferred to the space through a coil in the warm air duct. A heat pump is operated downstream of the solur heating coil in the duct to provide auxiliary heat. An electric resistance coil in the duct is also furnished for additional heat when required. Service hot water is heated by a singlewall tube bundle heat exchanger immersed in the storage tank and $i$ s backed up by a 40-gallon electric water heater. 
No heat exchangers are utilized between the collector, the storage tank and the solar heating coil in the duct. The piping for the system is galvanized steel and the collector fluid is treated with corrosion inhibitor.

The system has been fully instrumented for performance evaluation and integrated into the National Solar Data Network. It has been operational intermittently since August 1977.

NOTE: The original design employed collectors having aluminum absorber plated and freeze. protection was provided by means of a nitrogen displacement system. These original units were replaced during 1977 with copper collectors because of glazing fractures and the nitrogen system was replaced with an atmospheric drain-down.

III. SITE AND BUILDING DESCRIPTION

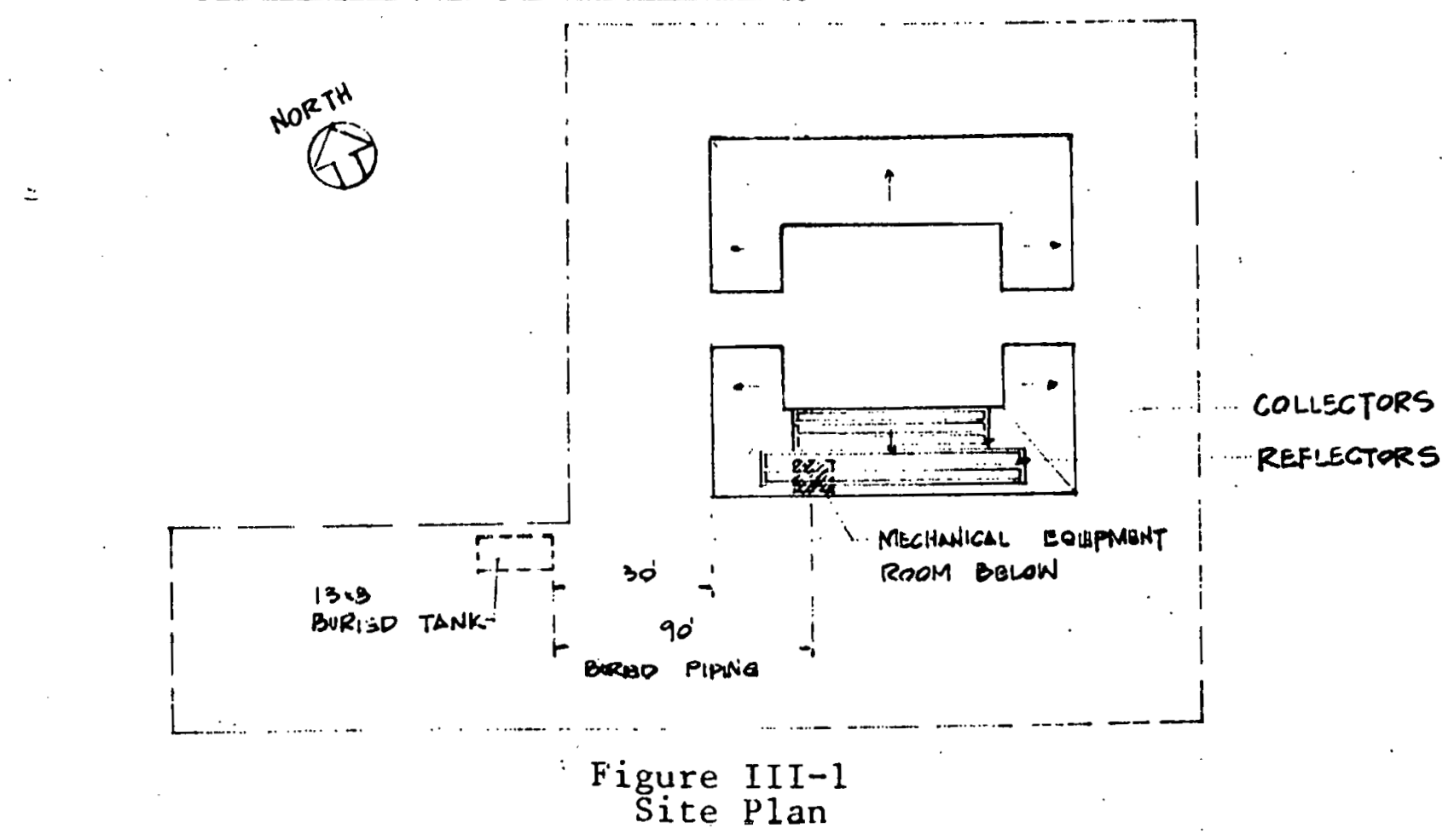


Site Description:

* Special topographic or climatic considerations - None

* Latitude $-34^{\circ} \mathrm{N}$

* Annual degree days $\left(65^{\circ} \mathrm{F}\right.$ base)

- Heating - 2621

o Cooling - 1775

- Data Location - Columbia, South Carolina

- Data Reference - "Local Climatological Data Annual Summaries for 1976," Department of Commerce, National Oceanic and Atmospheric Administration

* Average horizontal insolation

- January - $932 \mathrm{BTU} / \mathrm{FT}^{2}-\mathrm{Day}$

- July - $1926 \mathrm{BTU}^{2} \mathrm{FT}^{2}$-Day

- Data Location - Charleston, South Carolina

- Data Reference - Solar Heating Design by the F-Chart Method, Beckman, Klein, Dutfie, Wiley-Intersciencè Publication, 1977

* Site Topographic Description - Flat

* Shading - None

Building Description:

* Occupancy - Professional offices

* Total area - Approximately $9552 \mathrm{FT}^{2}$ 
* Solar conditioned area $-4284 \mathrm{Ft}^{2}$

* Height - Single story

* Roof slope - Pitched, 4 in 12

* Special features - Open inner court, $3 \mathrm{ft}$. overhang around exterior, $10 \mathrm{ft}$. overhang at courtyard

Structure:

* Walls (Solar conditioned space)

- Frame - 2 X 4 wood stud

- Exterior finish - Stucco on metal lath on gypsum board sheathing.

- Insulation - R-11, 3-1/2 in fiberglass batt

- Interior finish - Gypsum board

o Windows - Fixed and sliding doors, double glazed

o. Doors - Weather stripped, no vestibule

* Roof (Solar conditioned space)

- Frame - Pitched wood truss

- Insulation - Suspended 6 in fiberglass batts at ceiling, $\mathrm{R}-26$

- Exterior, finish - Asphalt shingles on $1 / 2$ in plywood sheathing

- Floor - Concrete slab on grade

Mechanical System:

* Heating

- Solar - Duct coil heat exchanger 
- Auxiliary - Air-to-air heat pump and electric resistance heating elements

o Distribution - Duct System

* Cooling (Non-solar)

- Auxiliary - Air-to-Air heat pump

- Distribution - Duct System

* Domestic Hot Water.

Deleted From Project

IV, SOLAR SYSTEM DESCRIPTION

General: Figure IV-I - Overall System Schematic.

Approximately eighty-five percent ( $85 \%$ ) of the building's heating requirements are provided by an hydronic solar system. The system uses roof mounted recirculating water cooper solar collection panels in conjunction with an underground hot water storage tank and recirculating pumps, piping, hot water coils and necessary instrumentation to automatically heat the system's hot water by radiated heat from the sun, and transfer this heat via the hot water coil to a conventional forced hot air ducted heating system for distribution to the office complex. The hot water system is closed and has the capability of being pressurized by nitrogen. Domestic city water mixed with one percent $(1 \%)$ by volume of corrosion inhibitor is utilized as the heat transfer medium. The same inhibited water that is recirculated through solar collection panels by the solar water pump is recirculated by the coil pump through an air heating hot water coil located in the duct system. There are no heat exchangers 


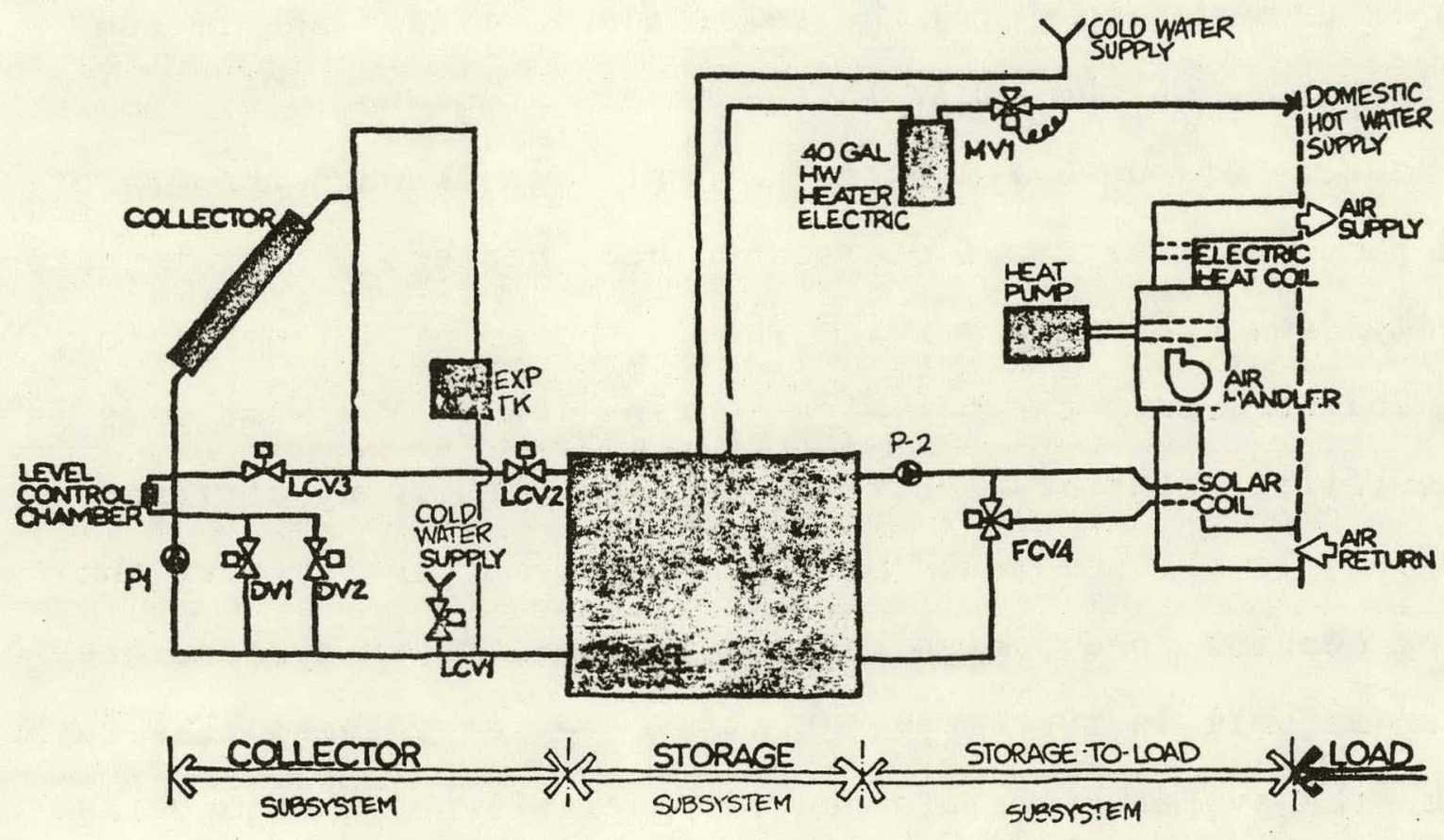

Figure IV -1

overall System schematic 
between the solar hot water and the coil hot water. Freeze provention of solar panels is accomplished by instrumentation which automatically drains the solar collectors anytime the temperature of the water in the storage tank is greater than the temperature of the water in the solar panels. A freeze protection back-up system is provided to drain the solar panels if for any reason the temperature of the water in the panels drops to $36^{\circ} \mathrm{F}$. Auxiliary heating of the building is arromplished through the use of a heat pump and electrical resistance duct heaters which are automatically sequenced into service should the solar hot water coil not be able to carry the building heating load. The heat pump is utilized first with the electrical duct heaters being utilized in stages only if the solar and heat pump systems cannot carry the building heating load. High and low pressure alarm systems are provided as well as system over pressure relief valves. The water level in the system is maintained automatically by a liquid level control syslem. The roof mounted solar panel system is designed such that solar concentration on the panels is accomplished through the use of an aluminized mylar film which reflects additional sun rays onto the panels and increases the efficiency.

\section{A. COLLECT'OR ARRAY}

See Figure IV-2 - Collectors, Piping and System Components \& SDAS Sensors. Fifty-three (53) flat plate collectors are mounted at 45 degree Lilt angle in a redwood frame superstructure on the south roof of the building. The three banks of collectors form a saw-tooth 


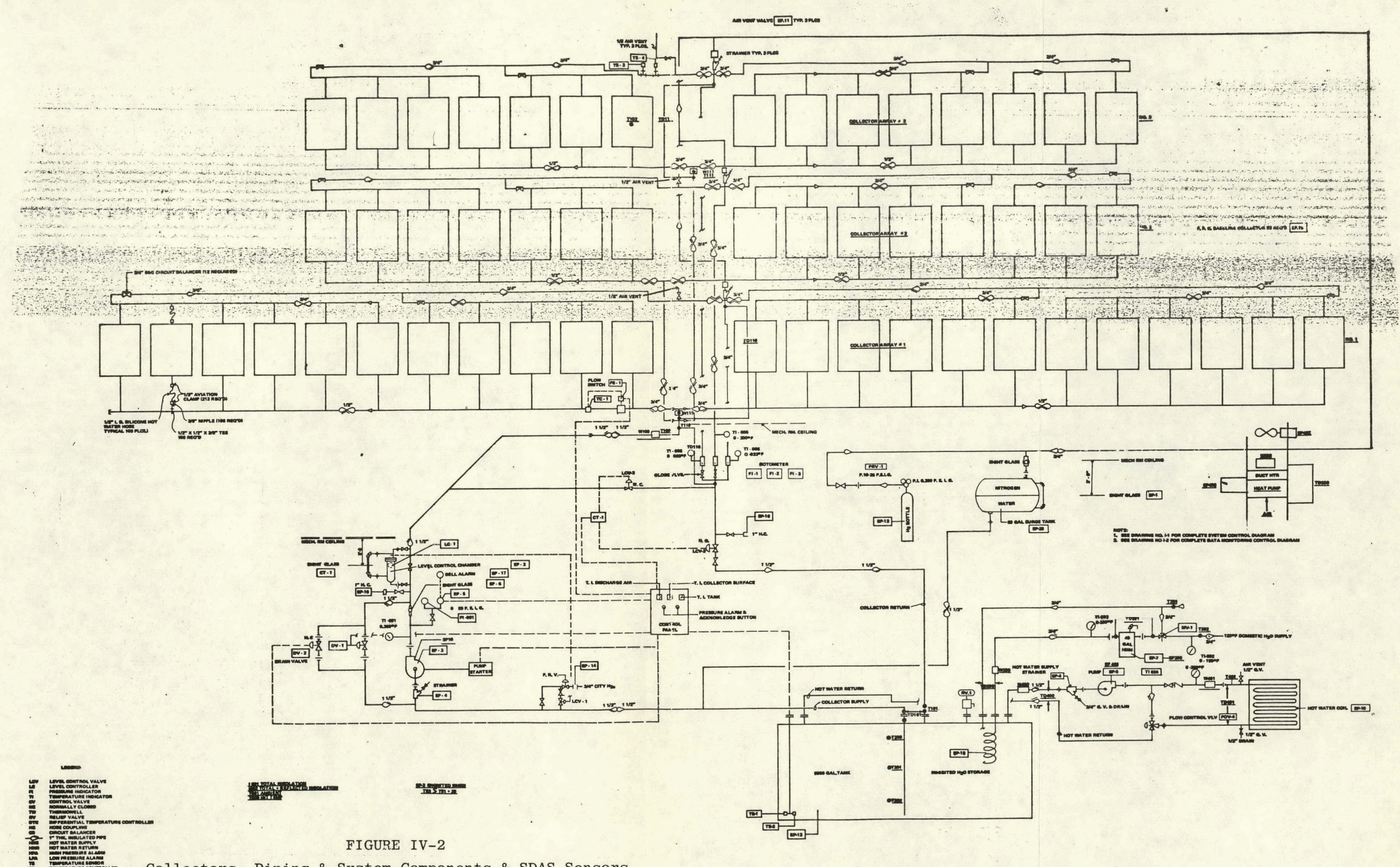

Collectors, Piping \& System Components \& SDAS Sensors 
pattern, and reflective mylar is mounted on the perpendicular face of each bank. Collector type is PPG, type I copper collectors with tempered double glazing. All collectors are fed by and discharged to insulated external headers constructed of schedule 40 galvanized carbon steel. High temperature, silicone rubber hose connects each collector to the headers, allowing for expansion and contraction.

\section{B. STORAGE SYSTEM}

A five thousand (5000) gallon steel tank 13'-6" long by $8^{\prime}-0^{\prime \prime}$ in diameter is located underground adjacent to the building. The tank is constructed of $1 / 4$ inch thick carbon steel plate with a rated operating pressure of 25 PSIG and temperature of $268^{\circ} \mathrm{F}$, and a bursting pressure of 100 PSIG. The tank is insulated with four (4") inches of "Foamglas", having a heat transfer coefficient of 0.085 $\mathrm{Btu} / \mathrm{Hr}-\mathrm{Ft}^{20} \mathrm{~F}$.

C. TRANSPORT FILIID

The transport fluid is potable, municipal water with a one percent (1\%) by volume concentration of corrosion inhibitor. Corrosion inhibitor is "Drewgard 100" as manufactured by the Drew Chemical Corporation.

D. TRANSPORT SYSTEM 
There are essentially two separate transport systems, the energy collecticn system and the energy utilization system. Both systems contain in-line centrifugal pumps and schedule 40 galvanized steel piping. All parts, including valves, strainers, fittings, etc., are "off the shelf" and commercially available. Normal maintenance in accordance with manufacturers' recommendations is followed.

E. SPACE HEATING SYSTEM

The primary source of space heat is from a two (2) row, fin-tube hot water coil located in the return duct. Auxiliary energy required for the system is provided first by a ten (10) ton heat pump and, if further energy is required, by $36 \mathrm{KW}$ electrical resistance duct heaters utilized in stages to satisfy the room thermostat.

F. SYSTEM CONTROL

\section{Control Logic}

Control of the solar pump and drain is by an electronic sensor 10cated on the center collector in the center array. The sensor is amplified and compared with an electronic sensor located in the solar water sump, near the bottom. When the temperature of the collector is $20^{\circ} \mathrm{F}$ greater than the sump water temperature, the control energizes the solar pump and closes the drain valves. When the solar water sump temperature is $3^{\circ} \mathrm{F}$ less than the temperature 
in the collectors, the pump will stop and the drain valve opens to empty the collectors. In addition, a remote bulb thermostat located at the lowest point on the collector on the roof will stop the solar pump and open the drain valve when the water temperature reaches $36^{\circ} \mathrm{F}$ to drain collectors to prevent freezing. Also, when the solar pump is energized, a solenoid valve will be closed by a control timer allowing both the collector panel supply and return water lines to fill up al lhe same time forcing the nitrogen in the lines through each of the water-air vent valves located above each bank of collectors. The control timer will then allow the normal recirculation of the collector water.

The air handling unit is programmed with a spring wound seven (7) day clock. When in the night cycle, a concealed adjustment night thermostat cycles the fan, and when the temperature falls below its setting, a timed over-ride switch returns to the day cycle.

For day cooling, the day thermostat cycles the unit fan and the cooling cycle of the heat pump upon demand. For day heating, the day thermostat cycles the unit fan and heating interlock relay. When the unit is calling for heat, the averaging bulb sensor in the unit discharge modulates the hot water 3-way valve to maintain $110^{\circ} \mathrm{F}$. If the valve is fully open and the temperature is below $100^{\circ} \mathrm{F}$, the heating cycle of the heat pump and electric duct heater in two stages are added in sequence through a sequencer to maintain the $100^{\circ} \mathrm{F}$ discharge temperature. 


\section{Control Parameters}

The day thermostat setting for space is $75^{\circ} \mathrm{F}$. This room therostat acting through the sequencer maintains a minimum supply air temperature of $100^{\circ} \mathrm{F}$ on the heating mode. The night thermostat acting through a time clock maintains a room temperature of $65^{\circ} \mathrm{F}$ once again utilizing $100^{\circ} \mathrm{F}$ supply air. The hot water coil threeway valve modulates the flow of pump up to a maximum of $20 \mathrm{CPM}$ at which time the sequencer utilizes the heat pump and electrical heat in stages to satisfy the room thermostat setting.

\section{Solar Collection System}

To prevent cycling of the solar pump on and off, an electronic sensor will not cycle the solar pump until the temperature of the solar panels is $20^{\circ} \mathrm{F}$ higher than the temperature of the water in the storage tank. This generally occurs around 9:00 a.m. The pump will then run, pumping .37 GPM per collector or a total of 20 GPM through fifty-three (53) collector panels until the collector temperature. At that time the pump will stop, causing a drain valve to open and drain the collectors and outside piping. The draining water displaces the nitrogen in the tank which fills the emptying collector with the inert gas.

\section{PERFORMANCE EVALUATION}

The National Program for Solar Heating \& Cooling is being conducted 
by the Department: of Energy under the Solar Heating and Cooling Demonstration Act of 1974. The overall goal of this activity is to accelerate the establishment of a viable solar energy industry and to stimulate its growth in order to achieve a substantial reduction in non-renewable energy resource consumption through widespread applications of solar heating and cooling technology.

Information gathered through the Demonstration Program is disseminated in a series of site-specific reports. These reports are issued as appropriate and may include such topics as:

Solar Project Description

Design/Construction Report

Project Costs

Maintenance and Reliability

Operational Experience

Monthly Performance

System Performance Evaluation

The International Business Machines Corporation is contributing to the overall goal of the Demonstration Act by monitoring, analyzing, and reporting the thermal performance of solar energy systems through analysis of measurements obtained by the National Solar Data Program.

The System Performance Evaluation Report is a product of the National jolar Data Program. Reports are issued periodically to document the 
results of analysis of specific solar energy system operational tional performance. This report includes system description, operational characteristics and capabilities, and an evaluation of actual versus expected performance. The Monthly Performance Report, is published on a regular basis. Each parameter presented in these reports as characteristics of system performance represents over 8,000 discrete measurements obtained each month by the National Solar Data Network.

These reports issued by the National Solar Data Program for Blakedale Professional Center solar energy system are listed below and can be obtained from the Department of Energy, Technical Information Center, P.O. Box 62, Oak Ridge, Tennessee. 37830 .

Solar Project Description - Solar/2014-78/50

Solar Energy System Performance Evaluation - Solar/2014-79/14

Monthly Performance Reports (Select Months) - Solar/2014-78/12

Solar Project Cúsl Report - Solar/2014-79/60. 
VI. SYSTEM PROBLEMS

As would be expected with the application of any new technology, several problems have surfaced to date. Without exception, all have been technical in nature. A brief discussion of the major problems encountered are contained herein.

\section{A. Cullector Breakage}

Probably the most frustrating and costly problem was with the original alumirum flat plate collectors. In July, 1976, after the collectors had been mounted in the redwood frames and secured, five collectors incurred broken glazing. $\Lambda$ call to PPG resulted in a prompt site visit by the sales representative, followed by months of negotiations. What was thought to be a satisfactory resolution occurred in March, 1977, when all fifty-three (53) aluminum collectors were replaced with new copper collectors at the manufacturer's expense. However, during reinstallation, several problems surfaced. Inlet and outlet connections had been relocated and resized, necessitating an expenditure for new silicone rubber tubing and manifold modifications, and modifications in the edge support framing. In addition, the manufacturer recommended that $3 / 8$ inch diameter weep holes be installed in each horizontal wooden member 
to allow for draining the bottom edge of each collector and prevent puddling. This recommendation apparently arose from the problem of moisture penetration of the collectors. An additional problem noted with the aluminum collectors was peeling of the flat black absorber paint.

\section{B. DROPPING STORAGE TANK TEMPERA'TURE}

It was noted that the storage tank temperature was dropping 5 to 10.degrees per night. It was thought that a high subsurface water table was transferring heat to the ground water, since the tank had not been completely. insulated. It was later found that a malfunctioning thermo-coupler was allowing the collector recirculation pump to run continuously, thereby rejecting heat to the atmosphere at night and on cloudy days. The thermo-coupler was repaired by the instrumentation manufacturer, Barber-Coleman, and the system was placed back in service less than a month later. However, the same thermo-coupler failed again, shutting down the system. It was found that the thermo-couplers initially installed could not function continuously at temperatures of $275^{\circ} \mathrm{F}$, and they were subsequently replaced.

In addition to the malfunctioning equipment, it was also substantiated that the ground water did result in heat loss from the tank. The tank was removed, completely insulated with four inches of Foamglas, and \#4 washed stone was added beneath and around the 
tank. No further problems of this nature have occurred.

POTABLE HO'T WATER

This part of project has been deleted due to small hot water requirement and cost associated with recirculating water for so smali a load.

C. CONTROLS

Far and away the biggest problems have been with controls. The design utilized 1975 off the shelf controls normally used in building hydronic systems since there was no "solar control industry" in 1975. The differential thermostats, cemperature sensors and associated relays and control components have all failed at one time or another and keep the system from ruming for any length of time. The Owner is planning a complete control revamp program with the U.S. Department of Energy at the time of this report and should have the system ready by Fall of 1980 . 
VII. APPENDIX

INSTALLATION DRAWINGS 


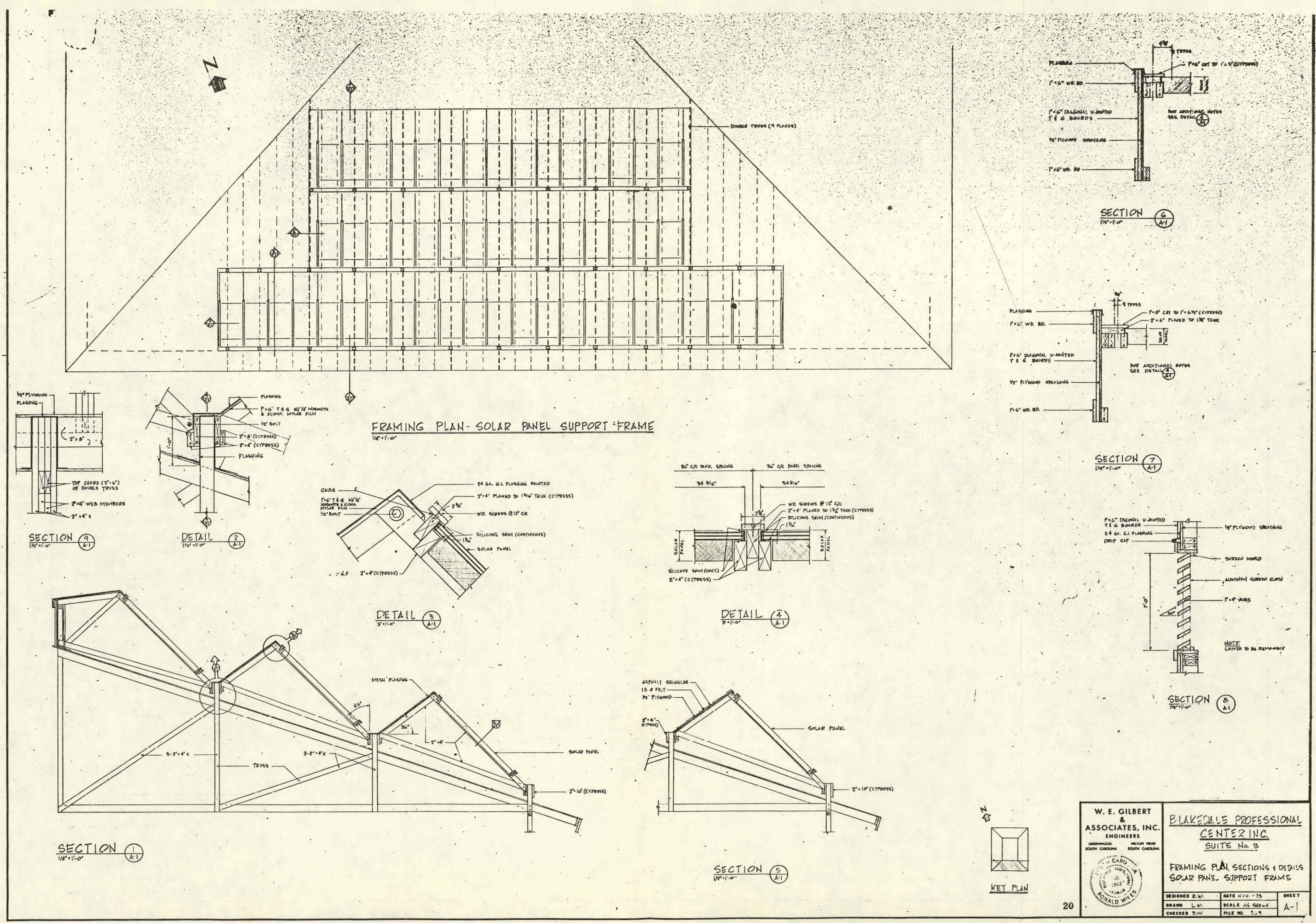




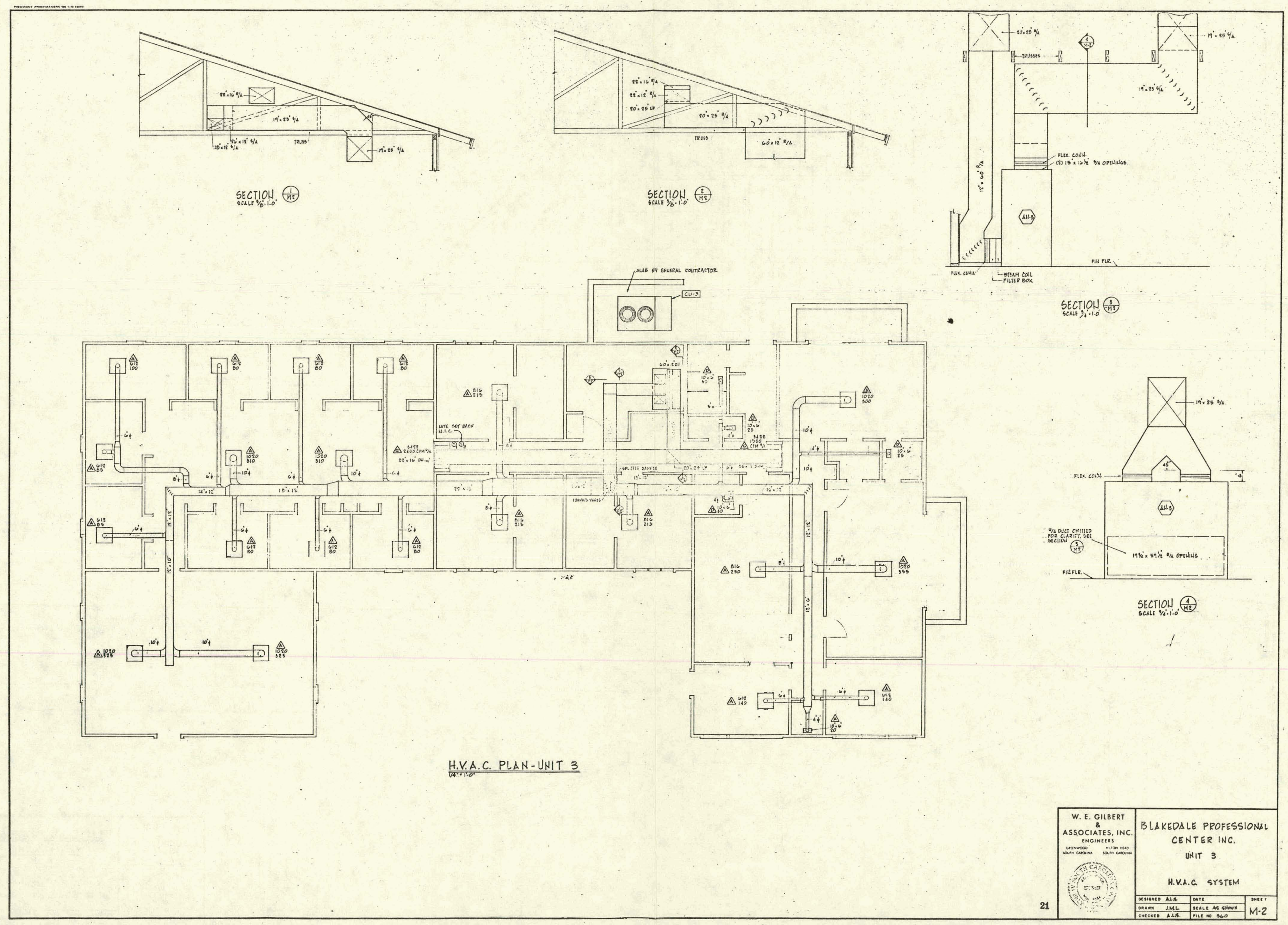




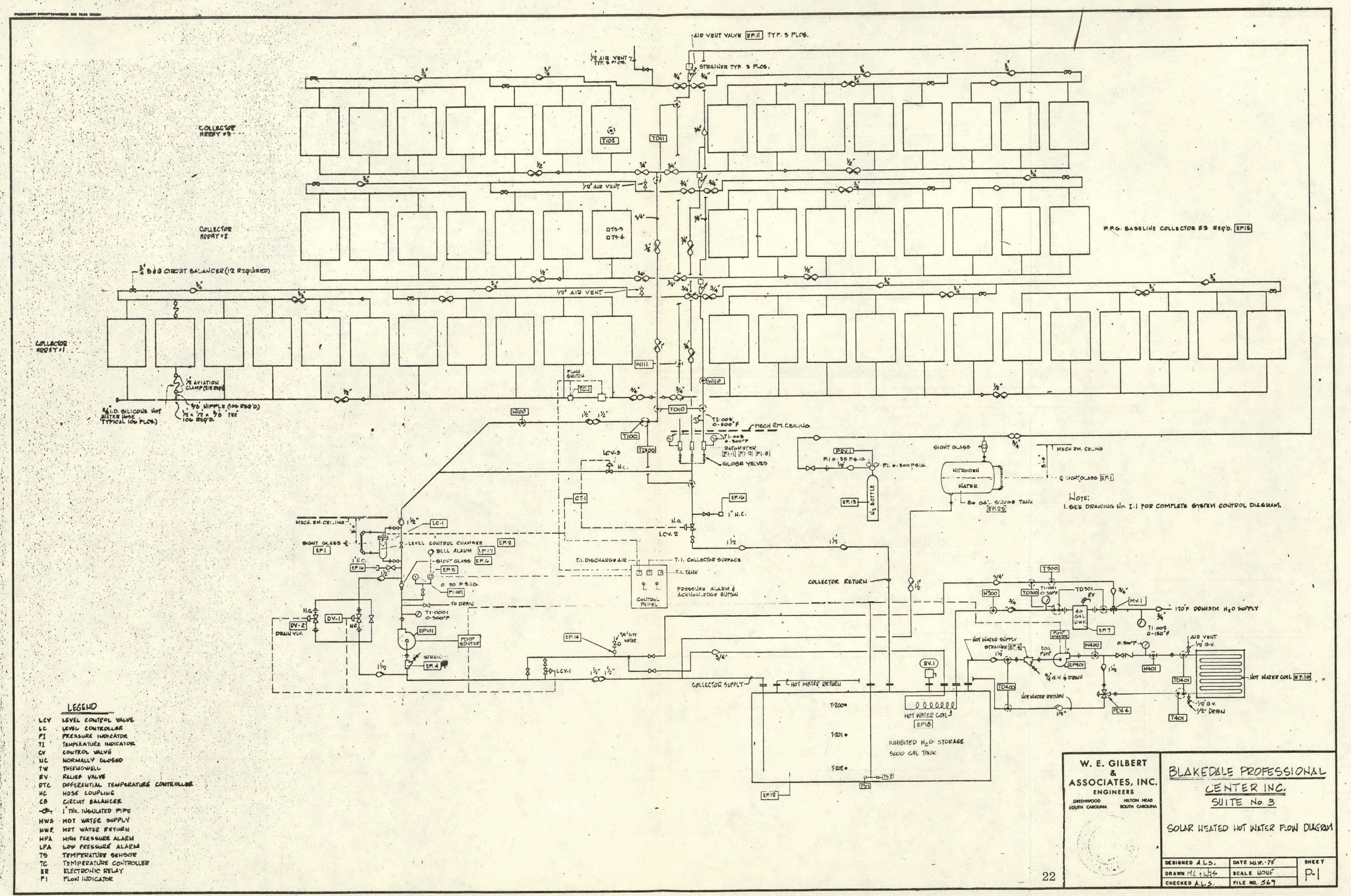




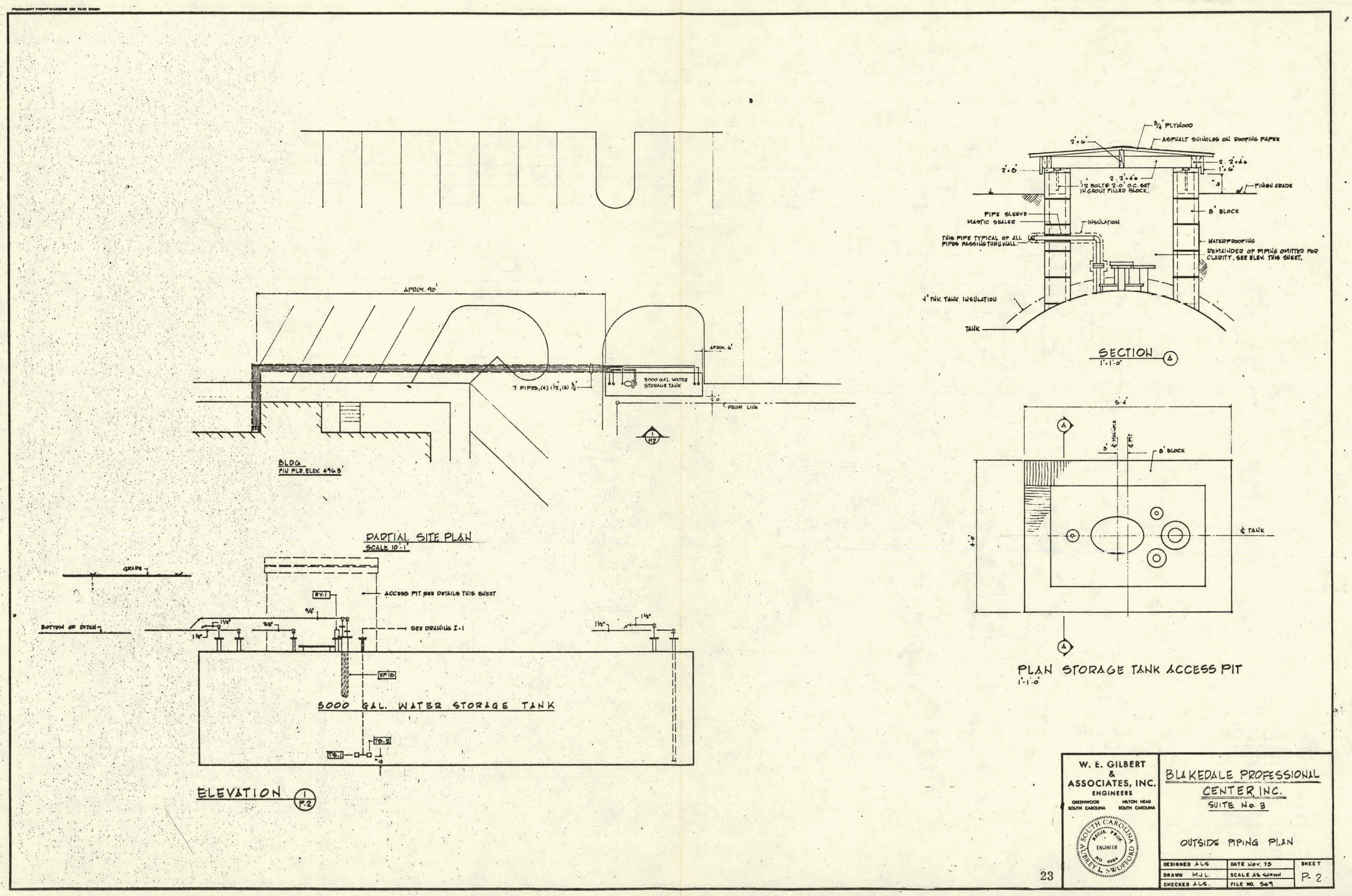




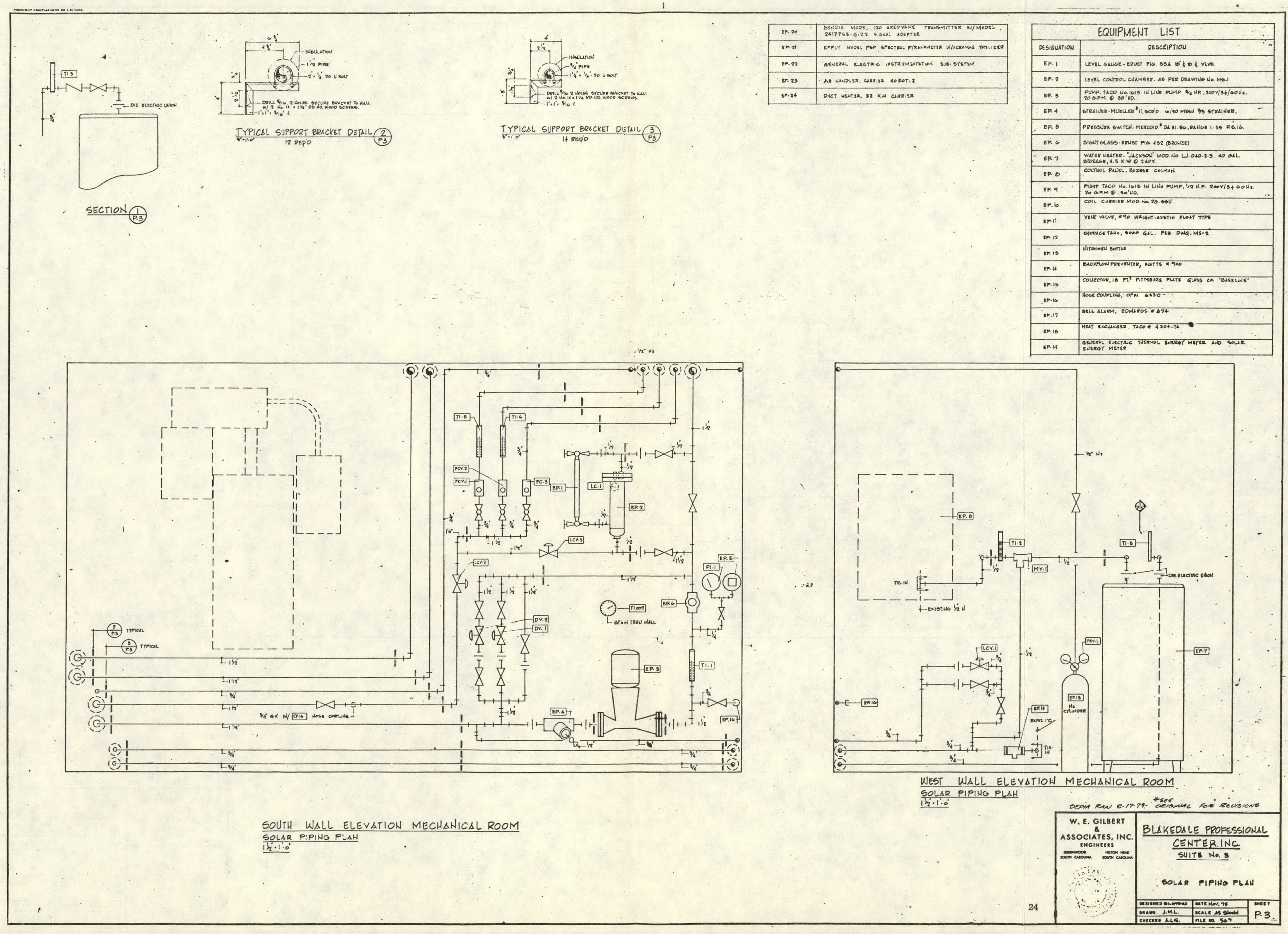




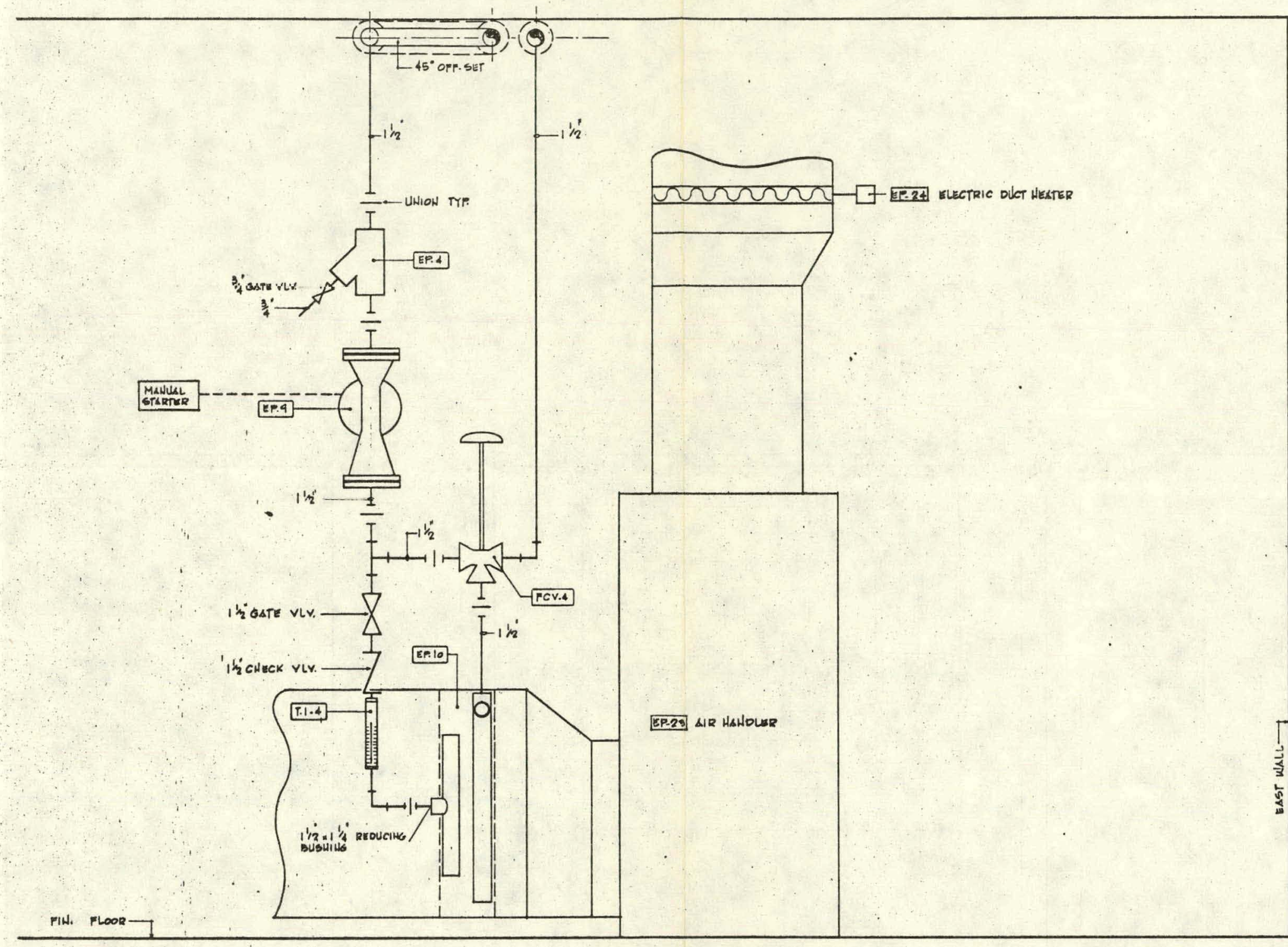

HORTH WALL ELEYATION MECHSNICAL ROOM SOLAR PIPING PLAS

\begin{tabular}{|c|c|}
\hline \multirow{3}{*}{ 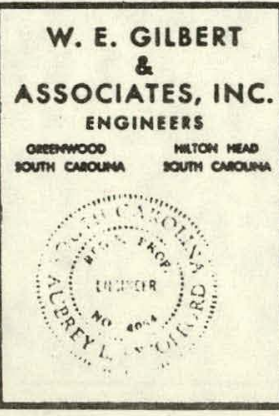 } & $\frac{\text { BLAKEOALE PROFESSIONAL }}{\frac{\text { CENTER.INC }}{\frac{\text { SUITE N. } 3}{N_{0} .3}}}$ \\
\hline & SOLAR PIPING PLAN \\
\hline & $b^{1 \cdot 0^{\prime}}$ \\
\hline
\end{tabular}




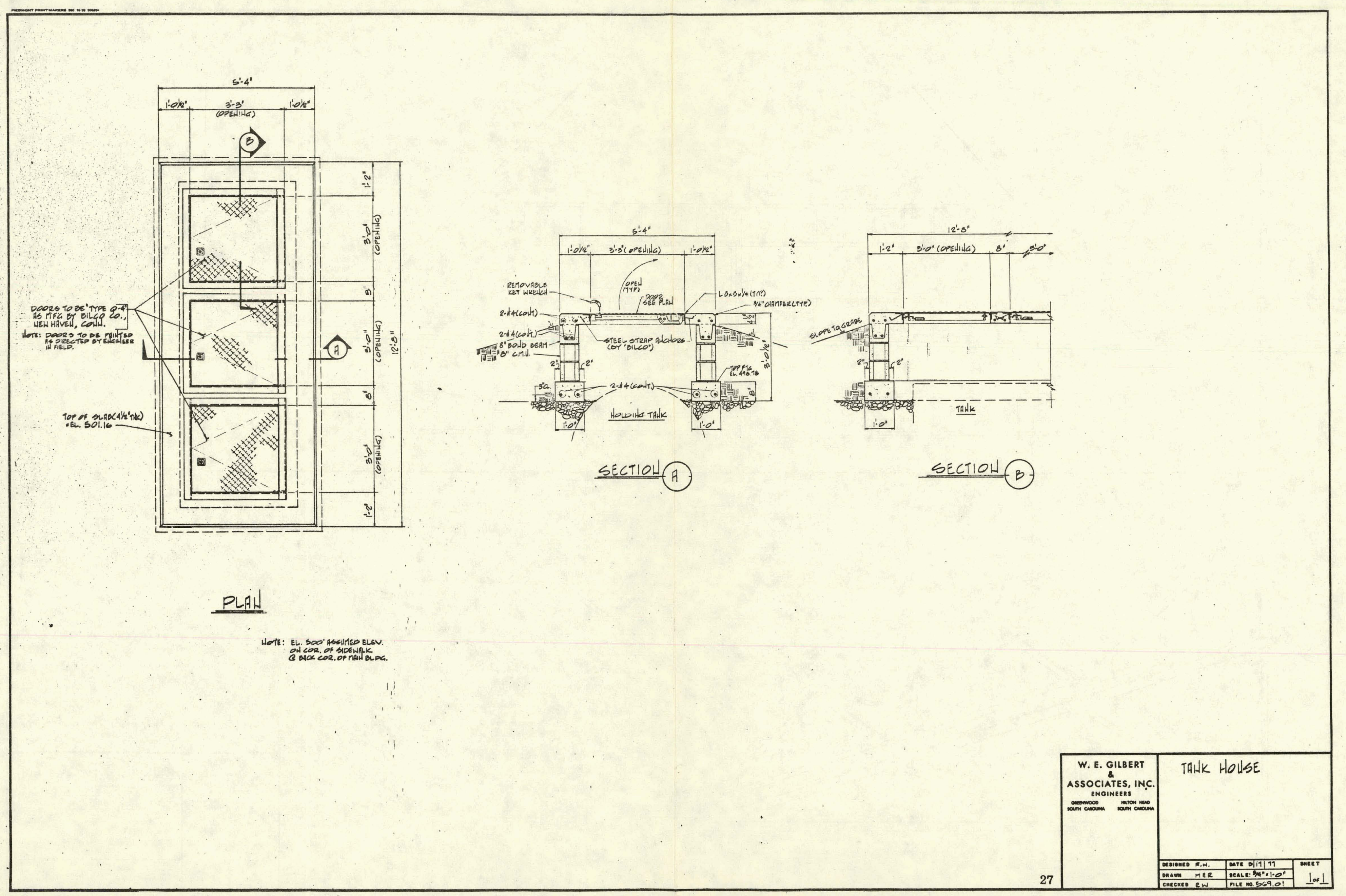




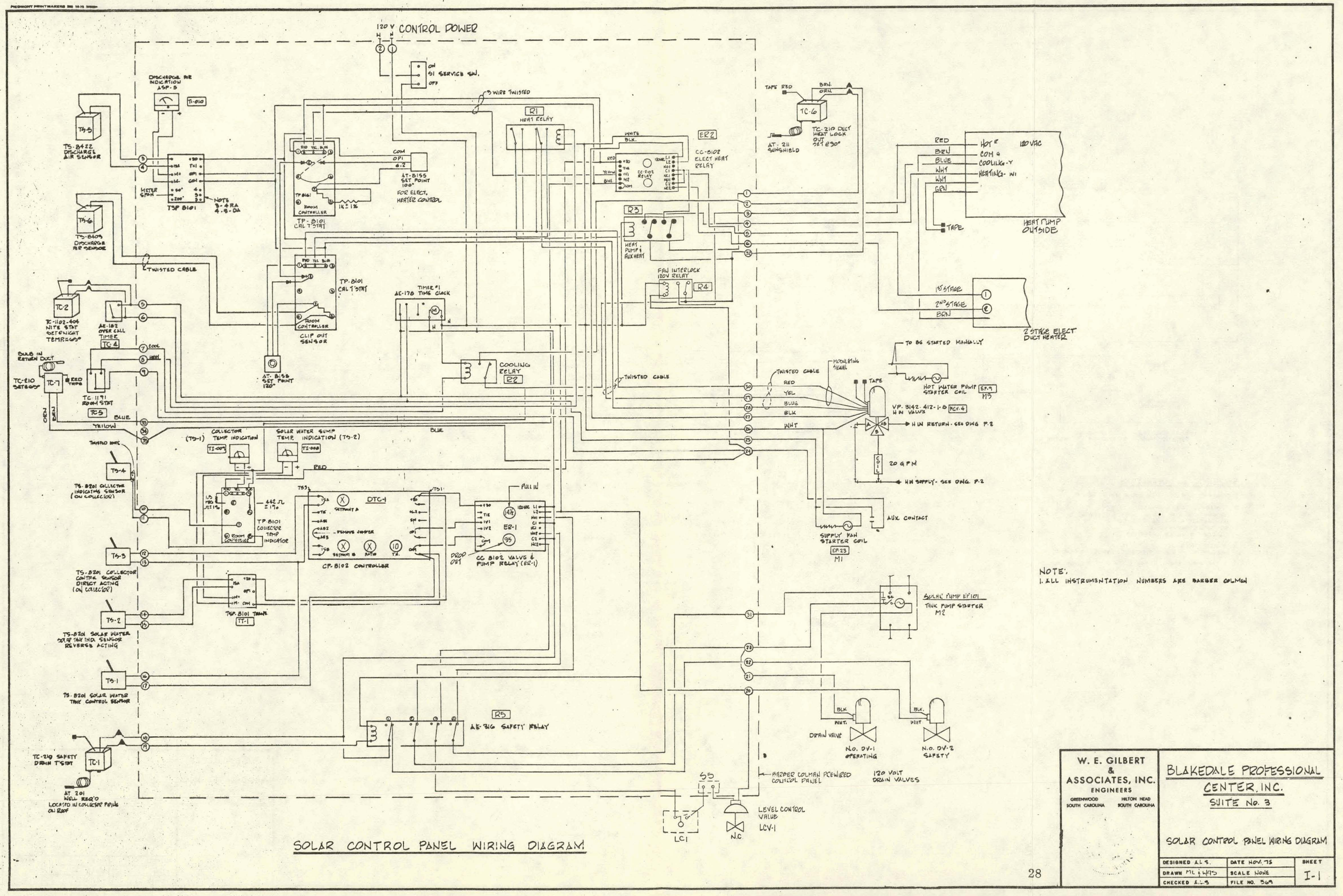



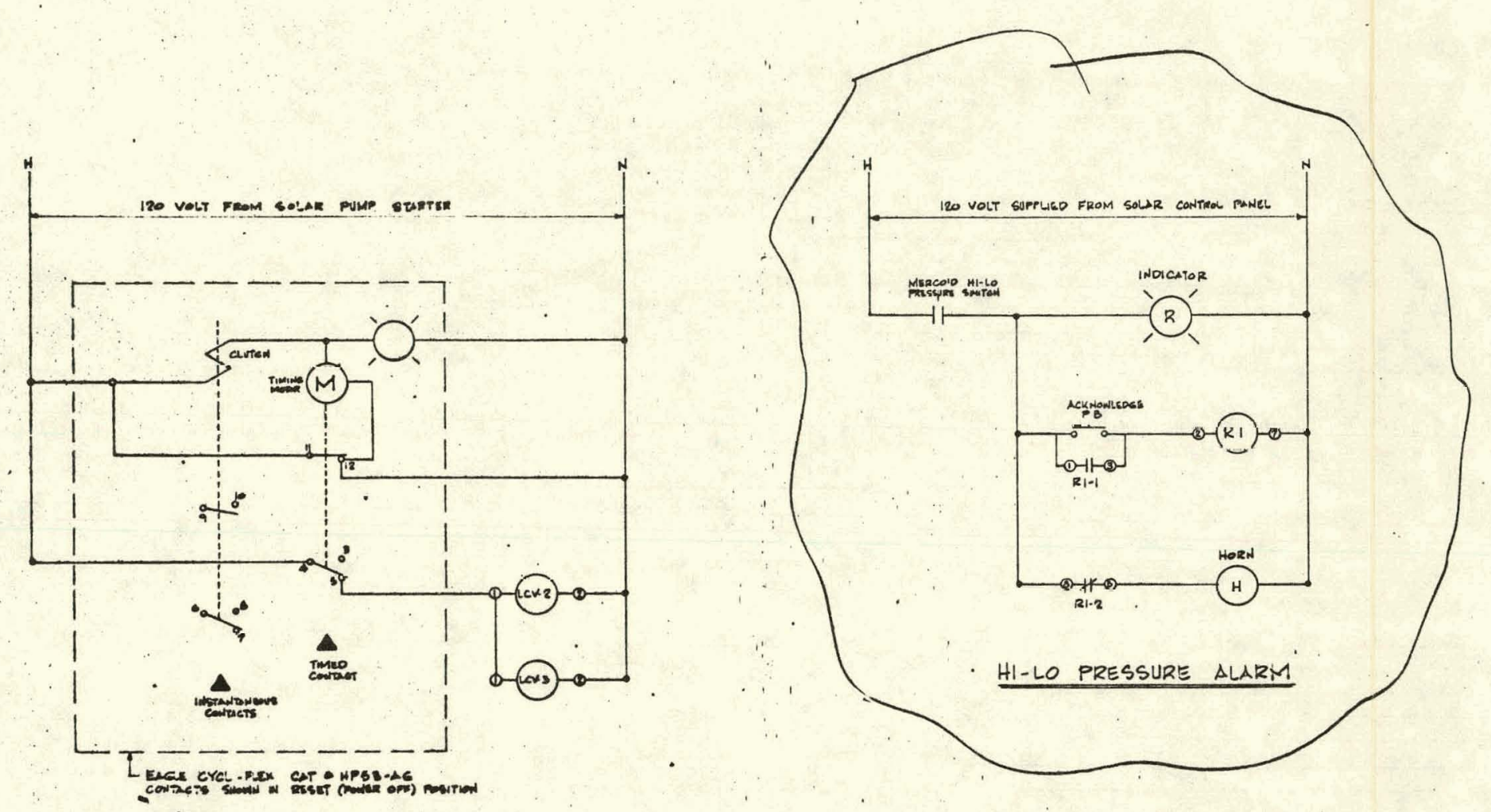

SEQNENCE ST OPERATION

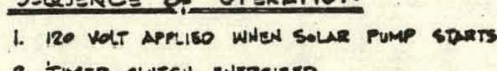

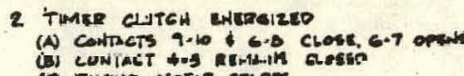

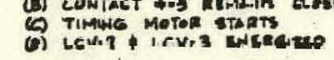

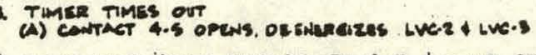

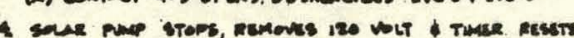

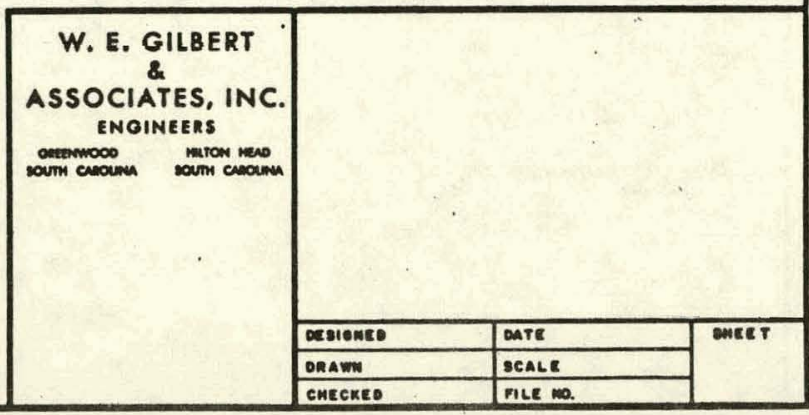




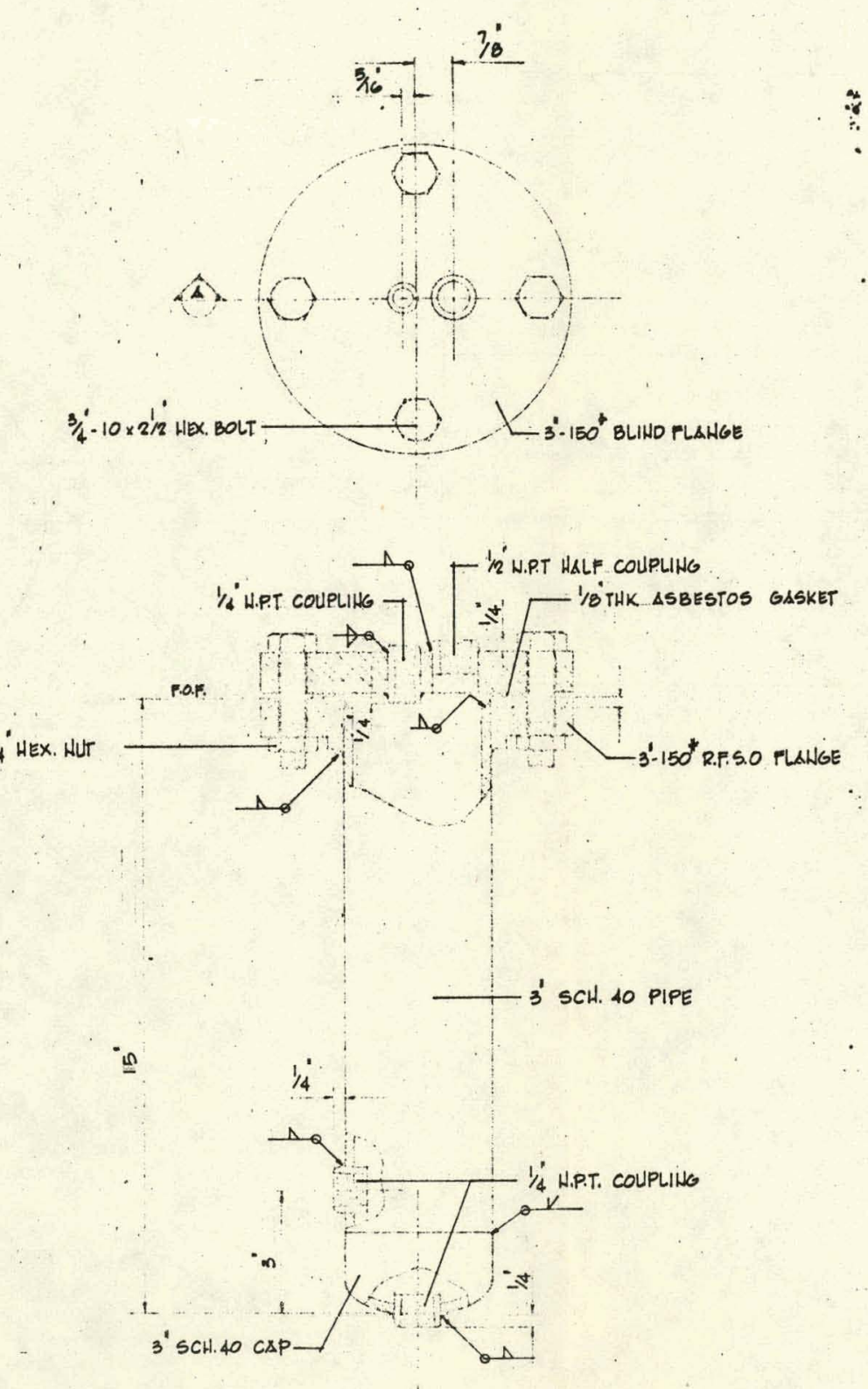

PARTIAL SECTION Ä 

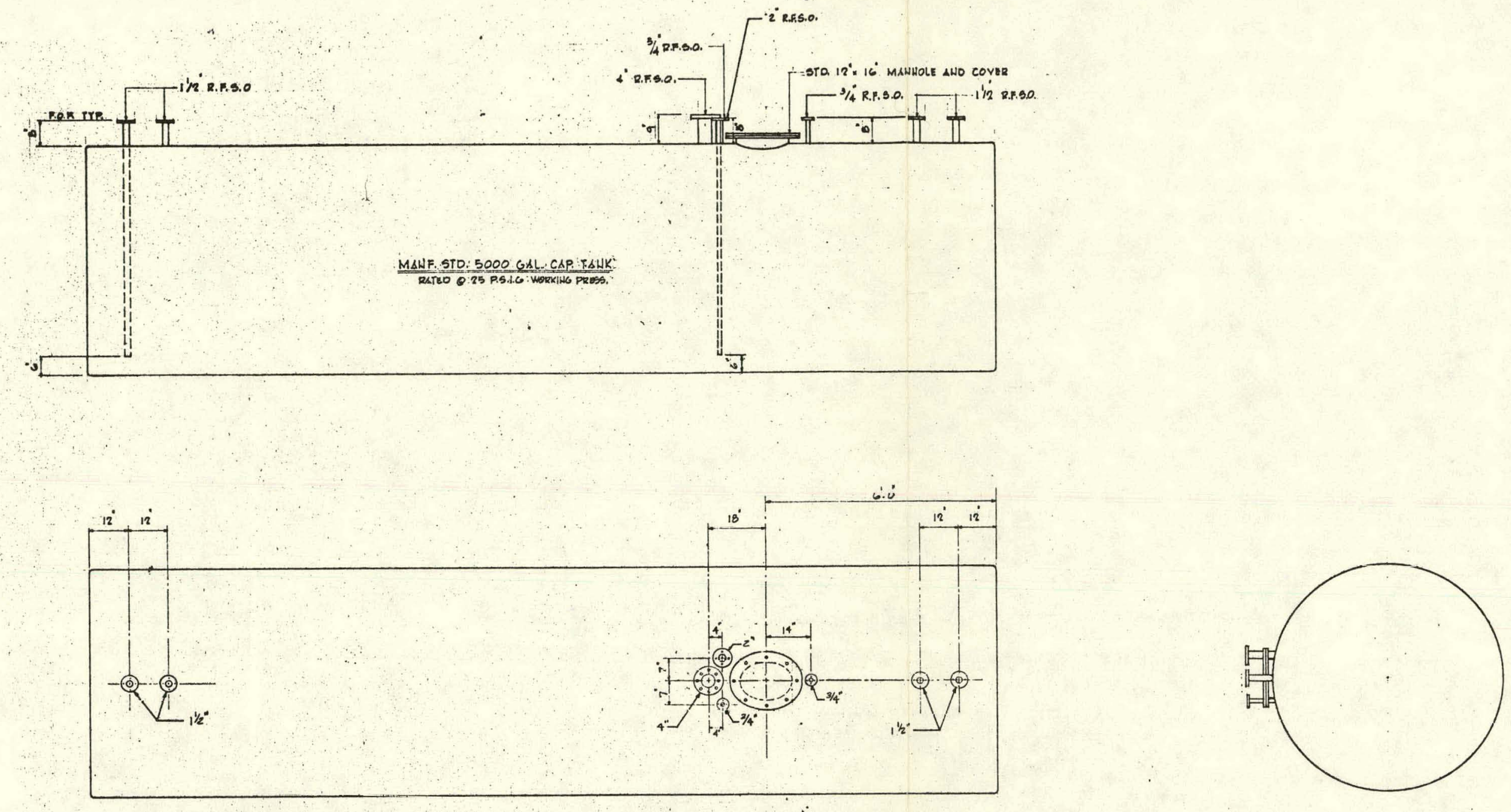

HOT WATER STORAGE TALK

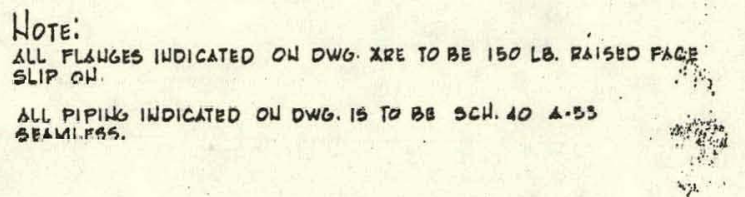

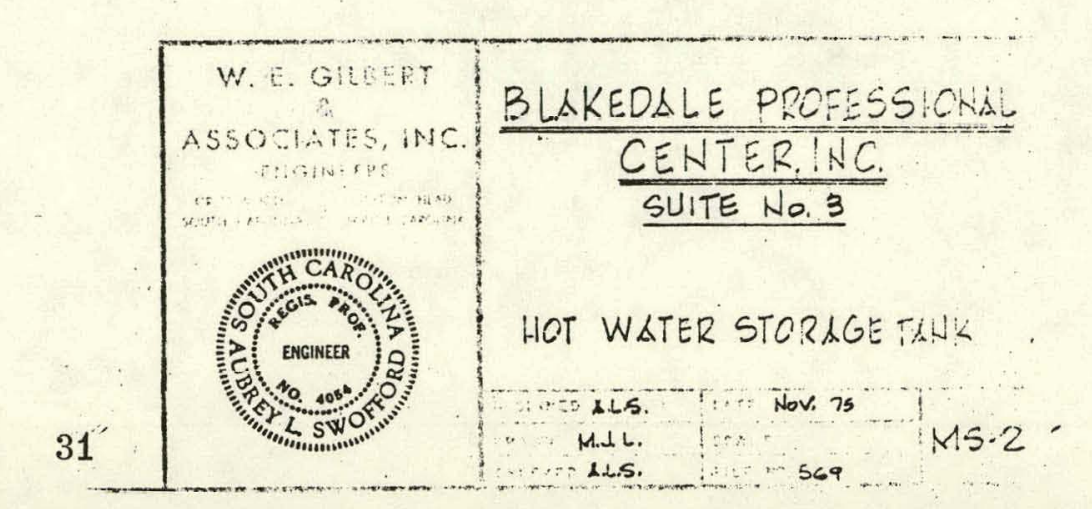

